\title{
INOVASI PENDIDIKAN DAN PERAN GURU
}

\author{
Beatris Lusmaria Putri Samat \\ Email: 1810111220003@mhs.ulm.ac.id \\ Program Studi Pendidikan Sejarah Fakultas Keguruandan Ilmu Pendidikan \\ Universitas Lambung Mangkurat \\ Banjarmasin
}

\begin{abstract}
Abstrak
Inovasi menekankan pada ciri adanya sesuatu yang diamati sebagai sesuatu yang baru bagi individu atau masyarakat sedangkan modernisasi menekankan pada adanya proses perubahan dari tradisional ke modern, atau dari yang belum maju ke yang sudah maju. Jadi dapat disimpulkan bahwa diterimanya suatu inovasi sebagai tanda adanya modernisasi. Misalnya untuk meningkatkan kesejahteraan perlu diadakan transmigrasi. Transmigrasi merupakan hal yang baru bagi masyarakat, maka transmigrasi adalah suatu inovasi. Masyarakat yang sudah mau menerima ide transmigrasi dan mau melaksanakan transmigrasi berarti sudah memenuhi ciri masyarakat modern yang siap menghadapi perubahan dan meninggalkan pola pikir tradisi yang bersemboyan (bahasa Jawa) "mangan ora mangan yen kumi" artinya meskipun tidak makan asal tetap berkumpul dengan sesama saudara.
\end{abstract}

\section{PENDAHULUAN}

Kata"innovation" (bahasa Inggris) sering diterjemahkan segala hal yang baru atau pembaharuan (S. Wojowasito, 1972), tetapi ada yang menjadikan kata innovation menjadi kata Indonesia yaitu"inovasi”. Inovasi kadang-kadang juga dipakai untuk menyatakan penemuan, karena hal yang baru itu hasil penemuan. Kata penemuan juga sering digunakan untuk menterjemahkan kata dari bahasa Inggris"discovery" dan"invention". Ada juga yang mengkaitkan antara pengertian inovasi dan modernisasi, karena keduanya membicarakan usaha pembaharuan.

Pada waktu membicarakan inovasi sering orang mengajukan pertanyaan tentang modernisasi, karena antara keduanya tampak persamaan yaitu kedua- duanya merupakan perubahan sosial. Agar dapat mengetahui apa perbedaan dan juga kaitan antara inovasi dan modernisasi, perlu dipahami apa inovasi dan apa modernisasi, baru kemudian dicari kaitan antara keduanya. Inovasi telah dibicarakan maka sekarang dibicarakan modernisasi. 
Inovasi pendidikan adalah inovasi dalam bidang pendidikan atau inovasi untuk memecahkan masalah pendidikan. Jadi inovasi pendidikan ialah suatu ide, barang, metode, yang dirasakan atau diamati sebagai hal yang baru bagi seseorang atau sekelompok orang (masyarakat) baik berupa hasil invensi atau diskaveri, yang digunakan untuk mencapai tujuan pendidikan atau untuk memecahkan masalah pendidikan.

Pendidikan adalah suatu sistem, maka inovasi pendidikan mencakup hal- hal yang berhubungan dengan komponen sistem pendidikan, baik sistem dalam arti sekolah, perguruan tinggi atau lembaga pendidikan yang lain, maupun sistem dalam arti yang luas misalnya sistem pendidikan nasional. Mattew B. Miller menjelaskan pengertian inovasi pendidikan sebagai berikut: "To give more concreteness the universe called "educational innovations" some samples are described billow. They are organized according to the aspect of a social system which they appear to be most clearly associated. In most cases social system involved should be taken to be that of a school or cell although some innovations take place within the context of many larger systems."

Jadi modernisasi pada dasarnya merupakan proses perkembangan, secara kebetulan Eropa Barat dan Amerika Utara telah berkembang lebih dahulu, dan sekarang bangsa dari dunia ketiga sedang berjuang untuk menyamakan diri mencapai status kehidupan modern. Dengan kata lain modernisasi adalah bekerja sama dengan dunia dengan maksud agar dapat meningkatkan hal-hal yang esensial dalam kehidupan, walaupun mungkin juga terjadi kekacauan atau perpecahan. (M. Francais Abraham, 1980:4).

\section{PERAN GURU SEBAGAI SEBUAH PROFESI}

Peran guru dalam inovasi dan pengembangan media pembelajaran sangat diperlukan mengingat guru dapat dikatakan sebagai pemain yang sangat berperan dalam proses belajar mengajar di kelas, hendaknya dapat mengolah kemampuannya untuk membuat media pembelajaran yang efektif dan efisien. Hal ini, menurut Wijaya dkk (1991:2), disebabkan perkembangan jaman yang terus terjadi tanpa henti dengan kurun waktu tertentu. Lembaga pendidikan hendaknya tidak hanya puas dengan metode dan teknik lama, yang menekankan pada metode hafalan, sehingga tidak atau kurang ada maknanya jika diterapkan pada masa sekarang. Perkembangan jaman yang begitu pesat dewasa ini membuat siswa semakin akrab dengan berbagai hal yang baru, seiring dengan perkembangan dunia informasi dan Komunikasi. Karena itu, sangat wajar jika kondisi ini harus diperhatikan oleh guru agar terus mengadakan pembaharuan (inovasi).

Untuk dapat merencanakan proses pembelajaran secara inovatif yang mampu memberikan pengalaman yang berguna bagi siswa kita perlu memperhatikan komponen penting proses pembelajaran. Dari komponen proses pembelajaran itu guru dapat merencanakan kegiatan dan strategi pembelajaran yang relevan dengan 
tujuan belajar. Kemajuan teknologi informasi banyak membawa dampak positif bagi kemajuan dunia pendidikan dewasa ini. Khususnya teknologi komputer dan internet, baik dalam hal perangkat keras maupun perangkat lunak, memberikan banyak tawaran dan pilihan bagi dunia pendidikan untuk menunjang proses pembelajaran.

\section{GURU INDONESIA DAN TANTANGAN PROFESIONALISME}

Kita saat ini masuk kepada era revolusi industry 4.0,era serba digital dalam segala hal,mulai dari urusan dapur sampai urusan pendidikan dan pelayanan dalam segala hal,di bidang transformasi yang serba online,tidak ada lagi yang dinamakan susah dan sulit semua teknologi menawarkan fasilitas yang serba mudah dan memungkinkan. Begitu juga penulis kedudukan sebagai narasumber,sebagai fasilitator dan sebagai penulis,dimudahkan dengan hadirnya teknologi, juga sebagai arsiteknya di bidang pendidikan harus cepat beradaptasi dan cepat menguasai ilmu pengetahuan yang sudah berubah situasi dan kondisinya, widyaiswara tidak lagi menunggu jadwal mengajar secara klasikal tapi di tuntut untuk lebih pro aktif dalam beraktifitas dan berperan,harus mampu merubah mindset,pola pikiran kita yang klasik menjadi digital.

Guru yang pandai mengembangkan profesinya bisa disebut guru yang kompeten dan profesional. Pasal 1 UU menguraikan tentang hak dan kewajiban guru. UndangUndang Nomor 14 Tahun 2005 tentang Guru dan Dosen, jadi setiap guru harus melindungi hak dan kewajibannya sendiri. Kemampuan profesional merupakan kemampuan dasar yang harus dimiliki guru. Di Indonesia, tingkat penghormatan terhadap profesi guru tidak sebaik kedua negara tersebut, namun sejak penerapan kebijakan sertifikasi profesi guru, kemajuan yang signifikan telah dicapai.

\section{SIMPULAN}

Peran guru dalam inovasi dan pengembangan media pembelajaran sangat diperlukan mengingat guru dapat dikatakan sebagai pemain yang sangat berperan dalam proses belajar mengajar di kelas, hendaknya dapat mengolah kemampuannya untuk membuat media pembelajaran yang efektif dan efisien. Dari komponen proses pembelajaran itu guru dapat merencanakan kegiatan dan strategi pembelajaran yang relevan dengan tujuan belajar. Kemajuan teknologi informasi banyak membawa dampak positif bagi kemajuan dunia pendidikan dewasa ini. Khususnya teknologi komputer dan internet, baik dalam hal perangkat keras maupun perangkat lunak, memberikan banyak tawaran dan pilihan bagi dunia pendidikan untuk menunjang proses pembelajaran. 


\section{REFERENSI}

Anis, M. Z. A., Putro, H. P. N., Susanto, H., \&Hastuti, K. P. (2020). Historical Thinking Model in Achieving Cognitive Dimension of Indonesian History Learning.PalArch's Journal of Archaeology of Egypt/Egyptology, 17(7), 7894-7906.

Anis, M. Z. A., Susanto, H., \&Mardiani, F. (2021, February). Analysis of the Effectiveness of MPBH: The Mains of Mandai as a Saving Food in Banjarmasin Community. In The 2nd International Conference on Social Sciences Education (ICSSE 2020) (pp. 89-94).Atlantis Press.

Efendi, I., Prawitasari, M., \& Susanto, H. (2021).ImplementasiPenilaianPembelajaranPadaKurikulum 2013 Mata PelajaranSejarah.Prabayaksa: Journal of History Education, 1(1), 21-25.

Susanto, H. (2020). ProfesiKeguruan. Banjarmasin: FKIP UniversitasLambungMangkurat.

Susanto, H., \&Akmal, H. (2018).EfektivitasPenggunaanAplikasiPembelajaranBerbasis Mobile Smartphone Sebagai Media PengenalanSejarahLokalMasaRevolusiFisik Di Kalimantan Selatan PadaSiswaSekolahMenengahAtas.HISTORIA: Jurnal Program StudiPendidikanSejarah, 6(2), 197-206.

Susanto, H., Irmawati, I., Akmal, H., \& Abbas, E. W. (2021).Media Film DokumenterMasuknya Islam Ke Nusantara danPengaruhnyaTerhadapKeterampilanBerpikirKritisSiswa.HISTORIA: Jurnal Program StudiPendidikanSejarah, 9(1).

Wijaya, Cece. Dkk.1991. Upaya pembaharuan dalam pendidikan dan pengajaran.Bandung: Remaja Rosdakarya.

Wojowasito, S. 1972. Kamus Bahasa Indonesia. Bandung: Shinta Dharma Bandung

Abraham, F. (1980). Perspective on Modernization toward General Theory of Third World Development. Washington: University Press of America.

Miles, M. B. (1964). Innovation in Education. New York: Bureau of Publication.

https://education.viewsonic.com/moving-education-technology-forward-digital-era/ 